\title{
GEOTERMINIO VANDENS IR SAPROPELIO PROCEDŪRŲ ITAKA GYVENIMO KOKYBEI
}

\author{
Lolita Rapolienè \\ Klaipèdos Jūrininku sveikatos priežiūros centras, Klaipédos universitetas, \\ UAB Atostogu parkas
}

Raktažodžiai: geoterminis vanduo, sapropelis, gyvenimo kokybè.

\begin{abstract}
Santrauka
Pasaulyje geoterminiai ištekliai, tokie kaip karštosios versmès ar geoterminis vanduo, užima svarbią vietą sveikatingumo ir sveikatinimo sektoriuose. Balneoterapijos procedūros (terminis vanduo ir peloidai) turi termini, mechaninị, cheminị ir imunologini komponentą, kaip ir psichologini poveikị žmogaus organizmui. Tyrimo tikslas: nustatyti aukštos mineralizacijos geoterminio vandens ir sapropelio poveiki gyvenimo kokybei. Metodika. Tyrimas atliktas 2015 metais su 103 dalyviais, kurių amžiaus vidurkis buvo 39 metai. Dalyviai gavo 10-15 aukštos mineralizacijos $27,6 \mathrm{~g} / \mathrm{l}$ geoterminio vandens, jo kombinacijos su sapropelio aplikacijomis, sapropelio ịvyniojimo arba sapropelio vonių 15-40 min. procedūras. Su sveikata susijusios gyvenimo kokybès vertinimui naudotas SF-36 klausimynas. Skaičiavimai atlikti naudojant statistinị programų paketą SPSS 20. Rezultatai: nustatyta, kad fizini aktyvumą statistiškai reikšmingai padidina kombinuotos sapropelio ir geoterminio vandens mišinio vonios $(\mathrm{p}=0,041)$; energingumą- 15 min. geoterminio vandens vonios ( $p=0,009)$, jų kombinacija su sapropelio aplikacijomis $(\mathrm{p}=0,004)$ ir sapropelio ivvyniojimai $(\mathrm{p}=0,015)$; socialinę funkciją- sapropelio ịvyniojimai $(p=0,05)$; emocinę būklę pagerina geoterminio vandens ir sapropelio aplikaciju procedūros $(\mathrm{p}=0,019)$; bendrą sveikatą- $20 \mathrm{~min}$. geoterminio vandens procedūros $(\mathrm{p}=0,05)$. Teigiamas geoterminių vonių poveikis išlieka iki 4 mènesių po procedūrų $(\mathrm{p}=0,035)$. Išvada: geoterminio vandens ir sapropelio procedūros, tiek kartu, tiek atskirai reikšmingai pagerina bendrą sveikatą, funkcinę būklę ir gyvybingumą.
\end{abstract}

\section{Ivadas}

Balneologija yra mokslo sritis, kuri tyrinèja balneoterapijos gydomuoju mineraliniu vandeniu (vonios, gèrimas ir inhaliacijos), purvu ir dujomis metodus, pritaikymą ir poveiki terapiniams tikslams pasiekti. Ji apima įvairias disciplinas: mediciną, visuomenès sveikatą, hidrologiją, hidrogeologiją, hidrochemiją, fiziką, mikrobiologiją, fiziologiją, fizioterapiją, toksikologiją, epidemiologiją, sveikatos turizmą ir kt. (1). Mineralinis vanduo gaunamas ne tik iš natūralių šaltinių, bet ir iš dirbtinių gilių vandens gręžinių. Šis faktas lemia mineralinio vandens temperatūrą ir cheminę sudètį, kuri gali skirtis nuo netoli esančio natūralaus šaltinio. Didesnị ištirpusių kietųjų medžiagų kieki lemia milijonus metų vykstanti geocheminè erozija ir daugelis elementų yra geologinès kilmès dẻl irimo (urano, torio, kalio) ir tirpimo procesų $(2,3)$. Pasaulyje geoterminiai ištekliai, tokie kaip karštosios versmès ar geoterminis vanduo, užima svarbią vietą sveikatingumo ir sveikatinimo sektoriuose (4).

Balneoterapijos procedūrų poveikis žmogaus organizmui yra įvairus ir sudètingas, veikimo mechanizmas dar šifruojamas. Dauguma mokslininkų sutinka, kad jos turi terminị, mechaninị (hidrostatinè keliamoji jèga, spaudimas), chemini ir imunologini komponentą, kaip ir psichologini poveikį $(5,6)$. Vieno ar kelių balneoterapijos procedūrų poveikyje vyksta sveikimo procesai ịvairiose kūno sistemose ir organuose $(5,7)$. Mineralinių medžiagų poveikị sveikatai ir jų panaudojimą balneoterapijai tyrè eilè mokslininkų, vystydami medicininę geologiją (3,8-12). İrodyta, kad vandens terapija veikia kardiovaskulinę, kaulų-raumenų, endokrininę, autonominę nervu sistemas ir duoda teigiamus visuomenès sveikatai rezultatus (13-16). Remiantis 2013 metu FEMTEC (World federation of hydrotherapy and climatotherapy) - FoRST (Foundation for the Spa Scientific Research) jungtinio projekto studija, hidroterapija dažniausiai naudojama kaulų ligų (40\%), kvẻpavimo ligų (17\%), virškinimo trakto ligu (16\%) gydymui, nedidelè dalis ski- 
riama dermatologijai- $9 \%$, metabolinèms ligoms- $8 \%$, ginekologijai-6\%. Dažniausiai naudojami vidutinès ir aukštos mineralizacijos $\mathrm{Ca}, \mathrm{Mg}$, Na druskų, sulfatiniai ir karbonatiniai vandenys (17). Pagrindinis tikslas, dèl kurio amerikiečiai lanko geoterminio vandens procedūras, yra pagerinti sveikatą ir išvaizdą, išsivaduoti nuo streso, atgaivinti savo kūną ir mintis. Skirtingai nei Europoje, kur geoterminio vandens procedūros dažniau taikomos specifiniu medicininiu tikslu paveikti vieną ar kitą ligos padarinį, JAV vandens procedūras traktuoja kaip sveiką gyvensenos būdą; dažniausiai siekiama mankštintis, sumažinti streso įtaką, išsivaduoti nuo depresijos, numesti svorį, pailsèti, atsipalaiduoti (18).

Peloidai - medžiagos (durpès, sapropelis, molis ir kt.), susidariusios natūralių geologinių procesų metu, pasižyminčios specifinèmis fizinèmis, cheminėmis ir biologiškai aktyviomis savybėmis ir kompleksiniu farmakologinio poveikio spektru (19), naudojamos medicininès reabilitacijos ir (arba) kitose sveikatinimo veiklose, o sapropelis koloidinès struktūros dumblas, kurio sudètyje yra nuo 10 iki 50 proc. organinès kilmès medžiagų (pagal LR SAM įsakymą Nr. V-816). Sapropelis - (iš sen. gr. saprós - puvimas ir pelós - dumblas, purvas) - koloidinè struktūra, dumblingos nuoseddos ar nuogulos, susidariusios gèlų, stovinčių vandens telkinių (ežerų, tvenkinių, kūdrų) dugne. Sapropelio nuosédos yra vienos iš charakteringų Haloceno (jauniausios geologinès epochos) periodo darinių, kuriose atsispindi geologinių ir klimatinių sąlygų vystymasis, landšafto pasikeitimas po ledynų atsitraukimo (20). Sapropelio organinę masę sudaro: bitumai, vandenyje tirpios, lengvai hidrolizuojamos ir humusinès medžiagos, celiuliozé, ligninas, lipidai, aromatiniai eteriai, karotinoidai, ksantofilai, spiritai, rūgštys, sterinai, chlorofilo dariniai, fosfolipidai, aminorūgštys, cukrūs, angliavandeniai, metaloporfirinai, fenoliai, vitaminai. Terapinis peloidu veikimas priklauso nuo jų termo-, chemo- ir mechaninių savybių, kurios gerai išstudijuotos (Cara, 2000; Legido, 2007; Ferrand ir Yvon, 1991). Išoriškai naudojant sapropeli, per odoje, poodyje ir gleivinėse esančius receptorius paleidžiamos sudètingos daugiaplanès vietinès ir bendrinès organizmo reakcijos, kurių dėka pasireiškia teigiamas poveikis periferinès nervų sistemos, endokrininėms, širdies-kraujagyslių, virškinimo sistemų sutrikimams, gerinama kaulų-raumenų sistemos būklè, stimuliuojami metaboliniai procesai kepenyse, gydomos odos ir ginekologinès ligos, greitinamas uždegimo gijimas $(19,20)$.

Gyvenimo kokybės sampratos raidos užuomazgos randamos dar Aristotelio (384-322 m. pr. Kr.) veikaluose, kuriuose jis kalbejjo apie gyvenimo pilnatvę ir žmogaus laimès jausmą. Gyvenimo kokybè - tai daugialype sąvo- ka, apibrèžianti visokeriopą asmens ar visuomenės gerovę (dvasinę, emocinę, socialinę, fizinę). Tai sąvoka, pažyminti asmens laisvès pojūtį, žmogiškąsias teises ir siekị būti laimingam. Pagal PSO „Sveikata visiems XXI amžiuje“ politiką, Lietuvos gyventojų gyvenimo kokybę galima pagerinti, jeigu, be gyvenimo kokybès monitoringo, sveikos gyvensenos, kaip socialinès normos pripažinimo, bus skiriama daugiau dèmesio gyvenimo kokybei pagerinti pirminejje, antrinèje ir tretinèje sveikatos priežiūroje. Mums lieka surasti priemones, galinčias tai padaryti.

Geoterminio vandens tyrimų pasaulyje nėra daug, o Lietuvoje pirmieji žingsniai žengti 2011 metais. Panaši situacija su sapropeliu- jo poveikio tyrimai Lietuvoje tik pradedami.

Tyrimo tikslas: nustatyti aukštos mineralizacijos geoterminio vandens ir sapropelio poveiki gyvenimo kokybei.

\section{Tyrimo metodika}

Tyrimas atliktas $2015 \mathrm{~m}$ vasario-birželio mènesiais Klaipėdoje, UAB Atostogų parkas SPA centre. Iš viso ị tyrimą buvo įtraukti 103 dalyviai; vertinti geoterminio vandens ir sapropelio poveiki ịtrauktos 90 anketų; 13 dalyvių nebaigè procedūrų kurso (13\%) dèl asmeninių priežasčių; dèl nepageidaujamų reiškinių procedūros nei vienam dalyviui nebuvo nutrauktos. Visi dalyviai buvo ištirti ir įtraukiami i tyrimą apmokyto bendrosios praktikos gydytojo. İtraukimo kriterijai: 18-65 metų abiejų lyčių atstovai, paskutinių 3 ménesių laikotarpiu negavę jokių reabilitacijos procedūrų, šiuo metu neturintys ūmių odos, ūmių šlapimo takų ligų, infekcijos, aktyvios tuberkuliozès, sunkios astmos, piktybinių auglių, sunkių nervų sistemos ligų (psichozè, neurozè, epilepsija), kepenų nepakankamumo, inkstų nepakankamumo, sunkaus širdies nepakankamumo, sunkios hipertenzijos, ramybès krūtinès anginos, sunkių ir nekoreguojamų endokrinologinių ligų (skydliaukès, kasos), neturintys širdies ritmo sutrikimų, kraujavimo, sunkios alergijos, didelio laipsnio nutukimo, nesant nëštumo ir norintys dalyvauti tyrime. Balneoterapijos procedūros skirtos ambulatoriškai, nekeičiant dalyvių dienos režimo. Prieš įtraukimą visi dalyviai buvo informuoti apie tyrimo tikslą, sąlygas ir pasirašè dalyvio sutikimą. Tiriamieji buvo suskirstyti i 5 grupes ir gavo 10-15 geoterminio vandens ar/ir sapropelio balneoprocedūrų. Pirmoji tiriamujų grupe buvo randomizuotai padalinta ị tiriamają ir kontrolinę (negavusią procedūrų) grupes (iš viso 30 moteriškos lyties, vidutiniškai $32 \mathrm{~m}$ amžiaus dalyvių). I grupei (tiriamajai) skirtos 15 min., II grupei- 20 min. trukmès geoterminio vandens procedūros (23 dalyvès, vidutiniškai $39 \mathrm{~m}$., po 15 procedūru), III grupei skirta $20 \mathrm{~min}$. sapropelio aplikacija ant kelio sąnario ir $20 \mathrm{~min}$. geoterminio vandens procedū- 
ra (18 dalyvių, vidutiniškai 43 m.,15 procedūrų), IV grupei skirti $40 \mathrm{~min}$. trukmès sapropelio ịvyniojimai ir $30 \mathrm{~min}$. veido kaukès (10 dalyvių, vidutiniškai $50 \mathrm{~m}$., 10 procedūrų), V grupei skirtos 20 min. sapropelio vonios (mišinys 3:1 dalimis) (9 dalyviai, vidutiniškai 50 m., 10 procedūrų). I grupès kontrolinio pogrupio dalyviai jokių procedūrų negavo, užsièmé sau ịprasta veikla ir atvyko po 3 savaičių būklès įvertinimui.

Su sveikata susijusi gyvenimo kokybė buvo įvertinta naudojant SF-36 klausimyną (trumpa sveikatos apklausos forma, angl. Short Form 36 Medical Outcomes Study questionnaire), kuri susideda iš 36 klausimų, atspindinčių aštuonias gyvenimo sritis: fizini aktyvumą, veiklos apribojimą dẻl fizinių negalavimų ir emocinių sutrikimų, socialinius ryšius, emocinę būseną, energingumą/gyvybingumą, skausmą ir bendrajj sveikatos vertinimą. Vertinimas buvo atliktas iškart po procedūrų, po 1, 2 ir 4 mėnesių (skirtingai grupèse).

Bendra dalyvių charakteristika pateikta 1 lentelèje.

1 lentelė. Visų dalyvių sociodemografinè ir klinikinė charakteristika

\begin{tabular}{|c|c|c|c|}
\hline Rodiklis & $\begin{array}{c}\text { Vidurkis } \\
\text { (SN) }\end{array}$ & Rodiklis & $\begin{array}{l}\text { Vidur- } \\
\text { kis (SN) }\end{array}$ \\
\hline $\begin{array}{l}\text { Amžius, m, vi- } \\
\text { durkis (SN) }\end{array}$ & $39,4(13,5)$ & Sergamumas & $\begin{array}{c}36 \\
(47,4)\end{array}$ \\
\hline $\begin{array}{l}\text { Ūgis, cm, vidur- } \\
\text { kis (SN) }\end{array}$ & $169,3(7,4)$ & Širdies ligos & $4(5,1)$ \\
\hline $\begin{array}{l}\text { Svoris, kg, vi- } \\
\text { durkis (SN) }\end{array}$ & $75,6(20,2)$ & $\begin{array}{l}\text { Virškinimo } \\
\text { sistemos ligos }\end{array}$ & $\begin{array}{c}12 \\
(15,4)\end{array}$ \\
\hline $\begin{array}{l}\text { Lytis, moterys, } \\
\text { N (\%) }\end{array}$ & $67(82,7)$ & $\begin{array}{c}\text { Endokrininès } \\
\text { ligos }\end{array}$ & $8(10,3)$ \\
\hline $\begin{array}{l}\text { Dirbantys kas- } \\
\text { dien, N (\%) }\end{array}$ & $54(68,4)$ & $\begin{array}{l}\text { Urologinès } \\
\text { ligos }\end{array}$ & $2(2,6)$ \\
\hline $\begin{array}{l}\text { Rūkymas kas- } \\
\text { dien, N (\%) }\end{array}$ & $15(19,2)$ & $\begin{array}{l}\text { Kaulu-raumenu } \\
\text { sistemos ligos }\end{array}$ & $\begin{array}{c}19 \\
(24,4)\end{array}$ \\
\hline $\begin{array}{l}\text { Alkoholio varto- } \\
\text { jimas kartą per } \\
\text { savaitę, N (\%) }\end{array}$ & $14(17,9)$ & Nervų ligos & $6(7,7)$ \\
\hline $\begin{array}{l}\text { Susiduriantys su } \\
\text { odai kenksmin- } \\
\text { gomis medžiago- } \\
\text { mis, N (\%) }\end{array}$ & $37(45,7)$ & $\begin{array}{l}\text { Kvèpavimo } \\
\text { ligos }\end{array}$ & $4(5,1)$ \\
\hline $\begin{array}{l}\text { Patiriantys fizini } \\
\text { krūvị, N (\%) }\end{array}$ & $21(31,8)$ & Akių ligos & $6(7,7)$ \\
\hline $\begin{array}{l}\text { Patiriantys psi- } \\
\text { chinị krūvị, N } \\
(\%)\end{array}$ & $34(51,5)$ & Odos ligos & $8(9,8)$ \\
\hline $\begin{array}{l}\text { Patiriantys fizini } \\
\text { ir psichini krū- } \\
\text { vius, } N(\%)\end{array}$ & $11(16,7)$ & $\begin{array}{l}\text { Vartoja vais- } \\
\text { tus }\end{array}$ & $\begin{array}{c}30 \\
(38,5)\end{array}$ \\
\hline
\end{tabular}

Tyrimui naudotas indiferentinès temperatūros $\left(34^{\circ} \mathrm{C}\right)$, didelès mineralizacijos 27,6 g/l UAB „Atostogu parkas“ tiekiamas geoterminis vanduo. Vandens cheminè sudètis pateikta 2 lenteleje. Geoterminis vanduo buvo silpnai šarminis, $\mathrm{pH}-7,24$, vandens bendras kietumas 173 , karbonatinis $-1,35$, katijonu/anijonu balansas +5.998 mg-ekv/l. Vandens cheminè sudètis- 2 lentelèje. Procedūroms su sapropeliu naudotas Rauškų ežero sapropelis (UAB Atostogų

2 lentelè. Geoterminio vandens sudètis

\begin{tabular}{|l|c|}
\hline Elementas & Koncentracija, $\mathbf{~ g / L ~}$ \\
\hline $\mathrm{Cl}^{-}$ & 16060 \\
\hline $\mathrm{Na}^{+}$ & 7040 \\
\hline $\mathrm{Ca}^{2+}$ & 2310 \\
\hline $\mathrm{Mg}^{2+}$ & 703 \\
\hline $\mathrm{SO}_{4}{ }^{-}$ & 1164 \\
\hline $\mathrm{K}^{+}$ & 187 \\
\hline $\mathrm{HCO}_{3}^{-}$ & 82,6 \\
\hline $\mathrm{Fe}$ bendra & 0,58 \\
\hline $\mathrm{F}^{-}$ & 0,16 \\
\hline $\mathrm{Mn}^{2+}$ & 0,2 \\
\hline $\begin{array}{l}\text { Ištirpusių mineralinių me- } \\
\text { džiagų suma }\end{array}$ & 27556 \\
\hline
\end{tabular}

3 lentelè. Sapropelio cheminè sudètis

\begin{tabular}{|c|c|}
\hline $\begin{array}{l}\text { Tyrimų parametras natūralioje } \\
\text { medžiagoje } \\
\text { Spalva }\end{array}$ & \begin{tabular}{|r} 
Rezultatas \\
Tamsiai ruda
\end{tabular} \\
\hline $\mathrm{pH}$ & 6,1 \\
\hline Drègmè, $\%$ & 94,13 \\
\hline Bendroji mineralizacija g/l & 4,92 \\
\hline \multicolumn{2}{|l|}{ Sausoje medžiagoje: } \\
\hline Pelenai, \% & 19,61 \\
\hline Organinė medžiaga, \% & 80,39 \\
\hline Bendras azotas $(\mathrm{N}), \%$ & 2,9765 \\
\hline Silicis $\left(\mathrm{SiO}_{2}\right), \%$ & 13,96 \\
\hline Bendras fosforas $(\mathrm{P}) \mathrm{mg} / \mathrm{kg}$ & 554 \\
\hline Bendras kalis $(\mathrm{K}) \mathrm{mg} / \mathrm{kg}$ & 2555 \\
\hline Bendras kalcis (Ca) mg/kg & 11499 \\
\hline Bendras magnis $(\mathrm{Mg}) \mathrm{mg} / \mathrm{kg}$ & 1786 \\
\hline Bendras natris $(\mathrm{Na}) \mathrm{mg} / \mathrm{kg}$ & 166 \\
\hline Bendra siera (S), mg/kg & 3740 \\
\hline Sulfatai $\left(\mathrm{SO}_{4}\right) \mathrm{mg} / \mathrm{kg}$ & 154 \\
\hline Chloridai $(\mathrm{Cl}) \mathrm{mg} / \mathrm{kg}$ & 96,6 \\
\hline Hidrokarbonatai $\left(\mathrm{HCO}_{3}\right) \mathrm{mg} / \mathrm{kg}$ & 6235 \\
\hline Cinkas $(\mathrm{Zn}) \mathrm{mg} / \mathrm{kg}$ & 98,9 \\
\hline Geležis $(\mathrm{Fe}) \mathrm{mg} / \mathrm{kg}$ & 8058 \\
\hline Huminių rūgščių kiekis, \% & 8,86 \\
\hline Fulvo rūgščių kiekis, \% & 4,34 \\
\hline
\end{tabular}


parkas). Taikytų aplikacijų/vonių temperatūra $38-40^{\circ}$ C. Sapropelio cheminè sudètis pateikta 3 lentelejje. Ekspozicijos trukmè 15-40 minučių.

Skaičiavimai atlikti naudojant statistini programų paketą SPSS 20. Tolydiesiems kintamiesiems vertinti buvo naudotas vidurkis ir jo vidutinis kvadratinis nuokrypis (SD) arba 95 proc. pasikliautinasis intervalas (PI). Nepriklausomų grupių kiekybinių parametrų statistiškai reikšmingiems vidurkių skirtumams ivvertinti naudotas t- testas, Wilcoxon ir $\mathrm{McNe}-$ mar testai. Ranginių dydžių sąryšiams nustatyti naudota Spearmen'o ranginè koreliacija. Laikyta, kad statistine išvada reikšminga, jei apskaičiuota kriterijaus tikimybė $\mathrm{p}$ tenkino sąlygą $\mathrm{p}<0,05$.

\section{Rezultatai}

Lyginant poveikio gyvenimo kokybei skirtumus tarp skirtingų procedūrų, paruošta 4 lentelè su teigiamo $(+)$ ar neigiamo (-) poveikio gyvenimo kokybès rodikliams pokyčio vidurkiu. Nustatyta, kad fizinį aktyvumą statistiškai reikšmingai padidina kombinuotos sapropelio ir geoterminio vandens mišinio vonios $(\mathrm{p}=0,041)$; energingumą- 15 min geoterminio vandens vonių procedūros $(\mathrm{p}=0,009)$, jų kombinacija su sapropelio aplikacijomis $(\mathrm{p}=0,004)$ ir sapropelio įvyniojimai $(\mathrm{p}=0,015)$; socialinę funkciją- sapropelio ịvyniojimai $(\mathrm{p}=0,05)$; emocinę būklę - geoterminio vandens ir sapropelio aplikacijų procedūros $(\mathrm{p}=0,019)$; bendrą sveikatą- $20 \mathrm{~min}$. geoterminio vandens procedūros

4 lentelė. Poveikio gyvenimo kokybei skirtumai grupėse (SF-36) *-reikšmingi pokyčiai grupess viduje. Vidurkiu prieš ir po palyginimui naudotas poriniu kintamuju T Testas.

\begin{tabular}{|c|c|c|c|c|c|c|}
\hline Rodiklis/grupė & I & II & III & IV & $\mathbf{V}$ & $\begin{array}{l}\text { Kon- } \\
\text { trolinè }\end{array}$ \\
\hline $\begin{array}{l}\text { Fizinis aktyvu- } \\
\text { mas, \% }\end{array}$ & $+1,8$ & $-0,3$ & +2 & $+3,9$ & $+4,4 *$ & $-1,1$ \\
\hline $\begin{array}{l}\text { Veiklos apribo- } \\
\text { jimas dèl fizinių } \\
\text { priežasčių, } \%\end{array}$ & $+3,9$ & $+1,8$ & $+5,9$ & $+22,2$ & $+8,3$ & $+3,2$ \\
\hline Skausmas, \% & $-0,5$ & $+3,7$ & $+8,5$ & $-1,2$ & $+8,6$ & $+11,1$ \\
\hline $\begin{array}{l}\text { Bendras sveikatos } \\
\text { vertinimas, } \%\end{array}$ & $+6,2$ & $+9,7 *$ & $+2,2$ & +6 & $+6,7$ & $+0,6$ \\
\hline $\begin{array}{l}\text { Energingumas/gy- } \\
\text { vybingumas, } \%\end{array}$ & $+11 \%$ & $+7,2$ & $+7,1^{*}$ & $+9,4 *$ & $+9,4$ & $-2,7$ \\
\hline $\begin{array}{l}\text { Socialinè funkci- } \\
\text { ja, \% }\end{array}$ & $+7,4$ & $+5,6$ & $+8,3$ & $+6,2 *$ & 0 & $+6,2$ \\
\hline $\begin{array}{l}\text { Veiklos apriboji- } \\
\text { mas dėl emocinių } \\
\text { priežasčių, \% }\end{array}$ & $+14,8$ & $+8,9$ & $+9,8$ & $+7,4$ & 0 & $-22,2$ \\
\hline Emocinè būklè, $\%$ & $+5,3$ & $+7,5$ & $+10,4 *$ & +8 & $+3,6$ & $-4,9$ \\
\hline
\end{tabular}

$(\mathrm{p}=0,05)$ (4 lent.).

1 paveikslëlyje pateiktas 15 min. geoterminio vandens vonių (I grupè) procedūrų poveikis gyvenimo kokybei po procedūrų, 1 ir 4 mėnesių. Vertinant pokytị visose gyvenimo srityse po procedūrų kurso, pagerẻjimas stebėtas septyniose iš jų. Reikšmingi pagerejjimai nustatyti energingumo/ gyvybingumo srityje (padidejimas vidutiniškai 11, 95\% PI nuo 18,82 iki 3,08; $\mathrm{p}=0,009$ ) bei bendrai vertinant sveikatą (vidutiniškai $6,2,95 \%$ PI nuo 12,58 iki $0,2, p=0,057$ ). Vertinant gyvenimo kokybę po 1 mėnesio po procedūrų su pradine, reikšmingi pokyčiai su didèjimo tendencija stebèti energingumo/gyvybingumo (pagerejo 12,8 vidutiniškai, $\mathrm{p}=0,003$ ), emocinès būklès (vidutiniškai $7,4, \mathrm{p}=0,054$ ) ir fizinio aktyvumo (vidutiniškai $2,8 \mathrm{p}=0,056$ ). Taigi, daugumoje sričių išliko ar net didejjo teigiamas procedūrų poveikis. Po 4 mėnesių išliko reikšmingas veiklos pagerèjimas veiklos emocinių sutrikimų $(p=0,035)$; nustatytas teigiamas poveikis energingumo/gyvybingumo lygiui ( $\mathrm{p}=0,061)$, sumažèjęs skausmas $(6 \%)$, socialinèje funkcijoje (7\%), emocinèje veikloje (8\%) (1 pav.).

SF-36 klausimyno rezultatu pokytis po 20 min. geoterminio vandens vonių kurso (II grupè) pavaizduotas pav.2. Patikimai pagerèjo bendras sveikatos vertinimas $(9,7 \%, \mathrm{p}=0,05)$.

Lyginant gyvenimo kokybès pokyti iki ir po kombinuotų (geoterminio vandens vonia ir sapropelio aplikacija- III grupè) procedūrų, nustatyti du reikšmingi teigiami pokyčiai: energingumo/gyvybingumo lygis padidèjo vidutiniškai $7,1(\mathrm{p}=0,004)$, emocinè būklè pagerèjo $10,4(\mathrm{p}=0,019)$ (3 pav.)

Po sapropelio ịvyniojimo procedūrų kurso buvo stebimi statistiškai reikšmingi teigiami pakitimai energingumo/ gyvybingumo $(\mathrm{p}=0,015)$ ir socialinès funkcijos kategorijose $(\mathrm{p}=0,05)$ (4 pav.). Po 2 mènesių po procedūru 
reikšmingų pokyčių nebuvo. Teigiami pokyčiai liko didesniame fiziniame aktyvume (vidutiniškai 1,3 ), bendrame sveikatos vertinime $(2,8)$, energingume $(3,8)$, socialinèje funkcijoje $(1,4)$, emocinèje būklèje $(2)$, skausme (4 pav.).

5 paveikslèlyje pateiktas sapropelio vonių (V grupè) poveikis gyvenimo kokybės rodikliams po procedūrų. Nustatyti teigiami pokyčiai 6 iš 8 svarbių sričių. Patikimas pokytis gautas fizinio aktyvumo srityje (vidutiniškai 4,4\%, $\mathrm{p}=0,041$ ).

\section{Rezultatų aptarimas}

Mūsų tyrimo metu nustatyta, kad UAB Atostogų parko išgaunamo

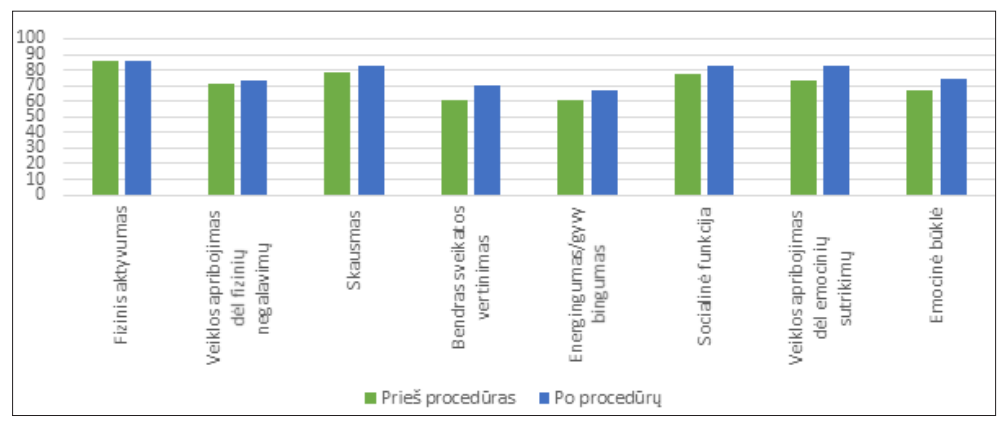

2 pav. Gyvenimo kokybės pokyčiai po 20 min. geoterminio vandens vonių procedūrų.

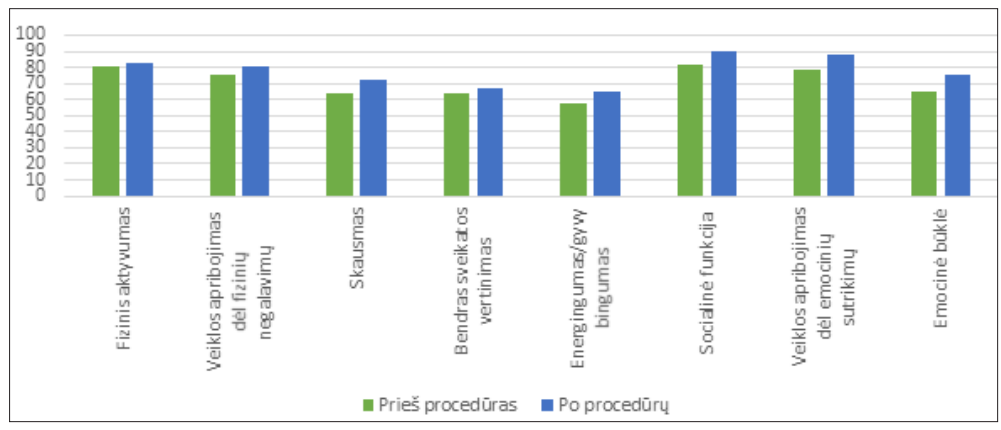

3 pav. Gyvenimo kokybės pokyčiai po kombinuotų procedūrų

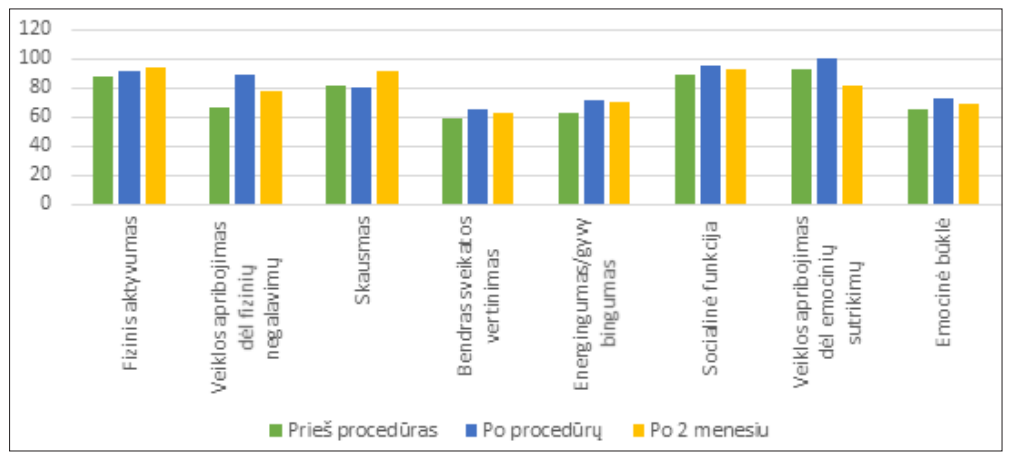

4 pav. Gyvenimo kokybės pokyčiai po sapropelio įvyniojimo procedūrų geoterminio vandens ir sapropelio procedūros gerina gyvenimo kokybę, kas gali būti naudinga organizmo stiprinimui ar atsistatymui po įvairių ligų ar traumų. Kitų autorių darbuose teigiama, kad mineralinis vanduo (geriamas, inhaliuojamas, vonių pavidalu) gali būti naudojamas ịvairioms vidaus ligoms gydyti (16). Psichiatrijoje SPA medicina dar nera pakankamai pripažistama (21). Iki šiol nèra išsamių atsipalaidavimo, gerovès jausmo, streso pojūčio mažejimo poveikių paaiškinimo; jie galimai susiję su ịvairių hormonų, kortizolio ar endogeninių opiatų pokyčiais (22). Sekine ir kt. nustate balneoterapijos procedūrų efektyvumą, gerinant gyvenimo kokybę, miego būklę, psichinę - emocinę savijautą, protinę veiklą (23). $\mathrm{Xu} \mathrm{Li}$ ir bendraautoriai ịrode, kad balneoterapija duoda teigiamą poveikị imuninei sistemai ir atlieka pagalbinį vaidmeni gerinant nuotaikos būklę, mažina įtampos, pykčio, nuovargio ir sumišimo nuotaikas bei didina jègą, gyvybingumą (24). Blasche $\mathrm{G}$ pilotine studija parode teigiamą SPA terapijos (balneoterapijos, masažo, mankštos, poilsio nuo darbo kombinacija) poveiki psichologiniams simptomams, susijusiems su darbiniu perdegimu (25).

Peloidų terapija populiari Turkijoje, Prancūzijoje, Vokietijoje, Italijoje ir Rytų Europoje; ji dažniausiai naudojama kaulų-raumenų sistemos ligų gydymui ir duoda teigiamus skausmą mažinančius rezultatus $(26,27)$. Bazzichi ir kt. studijoje su segančiaisiais fibromialgija stebejo purvo terapijos ir balneoterapijos poveikị skausmo, FIQ verčių mažinimui ir SF36 gerinimui. Nustatyta, kad purvo vonių terapija duoda ilgiau trunkančius rezultatus (28). Tefner ir bendraautoriai įrodè, kad ir Neydharting purvo paketai turi teigiamą poveiki klinikiniams parametrams, gyvenimo kokybei ir vaistų poreikiui sergantiesiems kelių osteoartritu (29). Gydymo Kolop purvu metu pagerèjo WOMAC skausmo, sustingimo, funkcijos skalès, EuroQol-5D gyvenimo kokybès indeksas po 12 savaičių buvo reikšmingai geresnis purvo grupejje, kaip ir bendros sveikatos būklès VAS skalè (30).

Remiantis Gutenbrunner ir kt (2010), viena iš balneologijos perspektyvu yra gydymo ir sveikatos netekimo prevencija, siekiant pagerinti bendrą sveikatos būklę, gerovę, pa- 


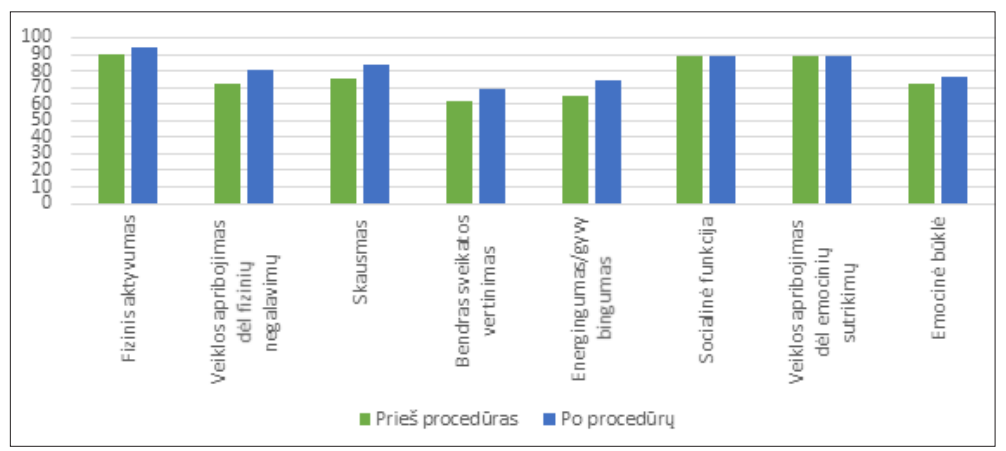

5 pav. Sapropelio vonių poveikis dalyvių gyvenimo kokybei

jègumą, sumažinti ar pašalinti esamus rizikos faktorius; sumažinti riziką esant tam tikroms kardiovaskulinėms, metabolinėms ir kitoms ligoms; pirminei prevencijai, siekiant sumažinti rizikos faktorių, patiriamų darbe ar gyvenime, elgesio pokyčių dèl gyvenimo pokyčių, streso, padidejjusio psichinio aktyvumo, nepilnavertès ir kitaip kenkiančios mitybos, organizmo funkcinių rodikliu pakitimu (kraujotakos, raumenu, metabolizmo) poveiki (31).

Tikra sveikata pasireškia ne tada, kai nesergame, o tada, kai yra gera bendra savijauta, energija, noras ir galios kurti gyvenimą, tai mūsų pačių ir gamtos sukurtas rezultatas.

Susidomejjimas geoterminio vandens panaudojimu sveikatinimui Europoje auga, kuriasi nauji reabilitacijos ar SPA centrai. Lietuva, lyginant su kaimynèmis šalimis, pasižymi palankiomis geoterminėmis sąlygomis, ypač vakariné šalies dalis, todèl būtų išmintinga jas panaudoti mūsų žmonių sveikatos gerinimo tikslu.

\section{Išvados}

1. Balneoterapija turi ilgą taikymo ir tyrinejjimo istoriją, daugèja paskelbtų studijų, tiriančių balneologinių medžiagų ir intervencijų mechanizmus, gydant fizinius ir psichoemocinius sveikatos sutrikimus.

2. Geoterminio vandens ir peloidų terapija yra saugūs, neinvaziniai, ekonomiškai naudingi, lengvai pasiekiami nefarmakologiniai organizmo autonominio reguliavimo metodai sergant ịvairiomis ligomis.

3. Geoterminio vandens ir sapropelio procedūros reikšmingai pagerina bendrą sveikatą, funkcinę būklę ir gyvybingumą.

\section{Literatūra}

1. Gomes CSF. Naturotherapies Based on Minerals, Geomaterials, 2013; 3:1-14

http://dx.doi.org/10.4236/gm.2013.31001

2. Bunnell JE, Finkelman RB, Centeno JA, Selinus O, "Medical Geology: A Globally Emerging Discipline," Geologica Acta, 2007; 5(3):273-281.
3. Gomes CSF, Silva JBP, "Minerals and Clay Minerals in Medical Geology," Applied Clay Science 2007; 36(1-3):4-21. http://dx.doi.org/10.1016/j.clay.2006.08.006

4. World Energy Resources: Geothermal World Energy Council 2013, http://www.worldenergy. org/wpcontent/uploads/2013/10/WER_2013_9_ Geothermal.pdf

5. Nassermoaddeli A., Kagamimori A. Balneotherapy in Medicine: A Review.Envoronmental Health and Preventive Medicine. 2005; 10:171-179. http://dx.doi.org/10.1007/BF02897707

6. Bond A.B. Balneotherapy: Healing with water. 1999, September25. http://www.care2.com/greenliving/balneotherapy_healing_with_water.html\#ixzz2Ufg1UGHs.

7. Ekmekcioglu C. Physiological Actions of Spa therapy on different systems of the body, Aix-Les-Bains, 2006.

8. Carretero I, Gomes C and Tateo F. "Clays and Human Health," In: F. Bergaya, B. Theng and G. Lagaly, Eds., Handbook of Clay Science, Developments in Clay Science, Elsevier Science, Amsterdam, 2006; 717-741. http://dx.doi.org/10.1016/S1572-4352(05)01024-X

9. Droy-Lefaix MT, Tateo F. "Clays and Clay Minerals as Drugs," In: F. Bergaya, B. Theng and G. Lagaly, Eds., Handbook of Clay Science, Developments in Clay Science, Elsevier Science, Amsterdam, 2006; 743-752.

http://dx.doi.org/10.1016/S1572-4352(05)01025-1

10. Gomes CSF, Silva JBP, "Products Based on Clay and Sand with Interest for Balneotherapy," Clay Science, 2006; 12(S2):228-232.

11. Lindh U, "Biological Functions of the Elements," In: O. Selinus, B. Alloway, J. A. Centeno, R. B. Finkelman, R. Fuge, U. Lindh and O. Smedley, Eds., Essentials of Medical Geology, Elsevier, Amsterdam, 2005; 115-160.

12. Veniale F, Bettero A, Jobstraibizer P and Setti M, "Thermal Muds: Perspectives of Innovation," Applied Clay Science 2007; 36(1-3):141-147. http://dx.doi.org/10.1016/j.clay.2006.04.013

13. Becker BE, Hildenbrand K, Whitcomb RK, Sanders JP. Biophysiologic Effects of Warm Water Immersion, International Journal of Aquatic Research and Education, 2009; 3: 24-37.

14. Bender T, Karagulle Z, Balint GP, Gutenbrunner C, Balint PV, Sukenik S. Hydrotherapy, balneotherapy and SPA treatment in pain management. Rheumatol Int. 2005; 25:220-224. http://dx.doi.org/10.1007/s00296-004-0487-4

15. Françon A, Forestier R. SPA therapy in rheumatology. Indications based on the clinical guidelines of the French National Authority for health and the European League Against Rheumatism, and the results of 19 randomized clinical trials. Bull Acad Natl Med 2009; 193(6):1345-56.

16. Fraioli A, Mennuni G, Grassi M. et al. SPA treatments of diseases pertaining to internal medicine. Clin Ter 2010; 161: e63-79. 
17. HydroGlobe. Definition of a global framework for hydrotherapy A FEMTEC - FoRST joint project with the cooperation of ISMH and the technical support oh WHO, Essentials from the final report, 2013. http://www.ismh-direct.net/upload/ismh/ document/HydroGlobe.pdf?web_id

18. Lund J. W. Geothermal SPAS in the Czech Republic and Slovakia. GHC bulletin. 2000 September; 35-37.

19. Platonov VV, Chadarcev AA, Čunosov SN, Fridzon KJ. Biologičeskoje deistvije sapropelia. Biological sciences. Fundamental research 2014 (9): 2474-2480.

20. Ponomariova MA. Chimičeskij sastav i puti ispolzovanije sapropelej Tatarstana. Doktorskaja disertacija, 2002. http:// www.dissercat.com/content/khimicheskii-sostav-i-puti-ispolzovaniya-sapropelei-tatarstana.

21. Maraver F, Karagulle Z. Medical hydrology and balneology: Environmental aspects, Serie de Monografias, 2012; 6 .

22. Toda M, MorimotoK, Nagsawa S, Kitamura K. Change in salivary physiological stress markers by SPA bathing. Biomedical Research 2006; 27:11-4. http://dx.doi.org/10.2220/biomedres.27.11

23. Sekine M, Nasermoaddeli A, Waqng H, Kanayma H, Kagamimori S. SPA resort use and health - related quality of life, sleep, sickness absence and hospital admission: The Japanese civil servants study. Complementary Therapies in Medicine 2006; 14:133-143.

http://dx.doi.org/10.1016/j.ctim.2005.10.004

24. Xu Li, Runze Shi, Bing Wang. et al. Effect of 3 Weeks of Balneotherapy on Immunological Parameters, Trace Metal Elements, and Mood States in Pilots, J. Phys. Ther. Sci 2013; 25: 51-54.

http://dx.doi.org/10.1589/jpts.25.51

25. Blasche G. Association of SPA therapy with improvement of psychological symptoms of occupational burnout. Forsch komplementmed 2010;17:132-6. http://dx.doi.org/10.1159/000315301

26. Bostan B, Sen U, Güneş T, Sahin SA, Sen C, Erdem M, Erkorkmaz U. Comparison of intra-articular hyaluronic acid injections and mud-pack therapy in the treatment of knee osteoarthritis. Acta Orthop Traumatol Turc 2010; 44(1):42-7. http://dx.doi.org/10.3944/AOTT.2010.2238

27. Bellometti S, Cecchettin M, Galzigna L. Mud pack therapy in osteoarthrosis. Changes in serum levels of chondrocyte markers. Clin Chim Acta 1997;268:101-6. http://dx.doi.org/10.1016/S0009-8981(97)00171-X

28. Bazzichi L1, Da Valle Y, Rossi A, Giacomelli C, Sernissi F, Giannaccini G, Betti L, Ciregia F, Giusti L, Scarpellini P, Dell'Osso L, Marazziti D, Bombardieri S, Lucacchini A. A Multidisciplinary approach to study the effects of balneotherapy and mud-bath therapy treatments on fibromyalgia. Clin Exp Rheumatol. 2013 Nov-Dec;31(6 Suppl 79):S111-20. Epub
2013 Dec 18.

29. Tefner IK1, Gaál R, Koroknai A, Ráthonyi A, Gáti T, Monduk P, Kiss E, Kovács C, Bálint G, Bender T. The effect of Neydharting mud-pack therapy on knee osteoarthritis: a randomized, controlled, double-blind follow-up pilot study. Rheumatol Int. 2013 Oct;33(10):2569-76. http://dx.doi.org/10.1007/s00296-013-2776-2

30. [Horváth R, Domoki M, Tóth É, Bender T, Tefner IK. The effects of Kolop peloid on knee osteoarthritis in day hospital care: a randomised, controlled, single-blind, follow up pilot study.Press Therm Climat 2013; 150:13-23.

31. Bender T, Balint G, Prohaszka Z, Geher P, Tefner IK. Evidence - based hydro - and balneotherapy in Hungary - a systematic review and meta - analysis. Int J Biometeorol 2013; 5.

\section{INFLUENCE OF GEOTHERMAL WATER AND SAPROPEL PROCEDURES ON QUALITY OF LIFE}

\section{Rapolienè}

Key words: geothermal water, sapropel, quality of life. Summary

Geothermal resources in the world, such as hot springs or geothermal water take an important role in the health and wellness sectors. The therapeutic effect of mineral water and peloids depends on chemical, thermal, mechanical, immunological component, as well as the psychological impact on the human body. Study objective: to evaluate the impact of high salinity geothermal water and sapropel for reinforcing quality of life. Methods. Research was made in Feb-Jun 2015. 103 (mean age 39 years) participants were divided into five groups and each group has got 10-15 different balneotherapy procedures daily five times a week with $27,6 \mathrm{~g} / 1$ salinity geothermal water or/and sapropel for 15-40 min. Outcomes measure: the Short Form (36) Health Survey. The statistical analysis of the data was performed by using the SPSS20 software package. Results: after the course of procedures the physical functioning was improved in sapropel baths group $(p=0,041)$; energy domain- in 15 min geothermal baths $(p=0,009)$, geothermal baths and sapropel application group $(\mathrm{p}=0,004)$ and sapropel wraps $\operatorname{group}(\mathrm{p}=0,015)$; social functioning- in sapropel wraps group $(\mathrm{p}=0,05)$; emotional well-being- in geothermal bath and sapropel application group $(p=0,019)$; general health- in 20 min geothermal baths group $(\mathrm{p}=0,05)$. The positive geothermal bath effect lasts up to 4 month after procedures $(p=0,035)$. Conclusion: Geothermal water and sapropel treatment, either together or separately significantly improves overall health, functional status and vitality.

Correspondence to: lolita.rapoliene@inbox.1t

Gauta 2015-10-12 